\title{
Early History of the Oral Contraceptive Pill in Finland: Diffusion of the New Contraceptive and Fertility Patterns
}

\author{
AURA PASILA, M.Soc.Sc., Project Researcher \\ Social Services Department, City of Helsinki, Finland
}

\section{Abstract}

The 1960s is often characterized as a decade of outstanding social and demographic changes in Western societies. The introduction of the contraceptive pill is assumed to have contributed to these changes. Yet the social as well as the demographic significance of the pill is ambiguous. This article has two aims: 1) to describe the early history of the pill in Finland in the 1960s and in the early 1970s and 2) to explore relationships between fertility and the pill. Surveys, pharmaceutical market data, and estimations are used to depict the diffusion of the pill. Based on calculated user percentages, the pill was adopted neither instantly nor extremely widely in Finland during the period under study. The results show that the diffusion coincided with fertility decline and other changes in fertility patterns. However, a causal connection of any kind cannot be established due to a lack of sufficient data.

Keywords: contraception, contraceptive pill, diffusion, Second Demographic Transition, fertility decline, Finland

\section{Introduction}

Wide-ranging social changes took place in many Western countries in the 1960s and 1970s. These decades have also attracted demographers' attention and it has been claimed that the 1960 s was a starting point of another demographic transition. The second demographic transition (SDT) theory, formulated by Dirk van de Kaa (1987) and Ron Lesthaeghe (1995), attempts to reconcile those sociocultural and demographic changes which began to emerge in the Western World in the 1960s. The decline of fertility to very low levels is pointed out as one of the most distinctive demographic changes of the time. According to the SDT theory, the emerging fertility patterns were intertwined with the adoption of more liberal values.

The core components of the SDT have been subject to criticism for multiple reasons (Cliquet 1991; Coleman 2004). It appears that another aspect of the theory requiring more attention is the unspecified role given to modern contraceptive technology. In the framework of the theory, the pill and the intrauterine device (IUD), which came 
to the market first in the 1960 s, are considered very important technological innovations. Yet it is stated that the introduction of the modern contraceptives was only a part of a wider change and similar type of development in fertility could have taken place in any case because of the deep transformation in people's view of life (van de Kaa 1987, 10, 26; see Ariès 1980, 649-650). In the context of the SDT the role of the contraceptive methods remains unclear, because no in-depth analyses have been made to scrutinize their relationship to fertility.

The bafflement over the significance of the modern contraceptive methods is not limited to the SDT theory. In general, the history of modern contraceptives has not been extensively studied from a demographic point of view. There appears to be two reasons for this. Firstly, in the field of demographic thinking the motivation to limit fertility is often seen as the most decisive factor affecting the number of children, whereas the means available are regarded as less important. Mere individual determination can be sufficient for fertility limitation, despite the lack of contraceptives. Evidence to support this view comes from the societies that experienced major fertility transitions in the $19^{\text {th }}$ and in the early $20^{\text {th }}$ century even though people did not usually use any contraceptives (Watkins 1986, 435). In addition to historical examples, the very low fertility level prevailing in present-day Japan is achieved by condoms, spermicides, the rhythm method, and abortion instead of modern hormonal contraceptives (Hayashi 2004; Leridon 2006, 604-605, 611). Thus, considering fertility as a purely demographic phenomenon, contraceptives can be seen to have only secondary importance.

The few studies concentrating on the effects of the contraceptives, here in particular those of the pill, provide conflicting results. The lack of data from the early phases of the introduction of the pill is a major factor contributing to the discrepancies. When the diffusion of the contraceptive pill has been studied in respect of the total fertility rate (TFR), no universal connection between the two has been found. The connection may be non-existent, weak or discontinuous (Leridon 2006). A more detailed study in Norway provides a possible explanation by concluding that the fertility effects of the pill were negligible because it was mainly adopted by women who already had a low risk of pregnancy (Østby 1989, 41).

In other studies the adoption of the pill, as well as its abandonment, has been shown to explain changes in fertility. The most detailed quantitative studies of the pill have been carried out in the United Kingdom and in the United States where the pill diffused rapidly and widely (Leridon 2006). In Britain the introduction of the pill in the 1960s made many women switch to a more effective contraception method. The share of women using contraception also increased slightly. The TFR declined in line with the diffusion of the pill. However, after two pill 'scares' caused by the publicity of its negative health effects, the growth in sales first stagnated and later decreased. In the latter case a rise in the TFR resulted (Murphy 1993). 
In the United States it has been possible to complete multiple analyses on the relationships between young women's fertility-related behavior, fertility, and the pill. They are based on the differential timing of the availability of the pill in the states. The studies show that the adoption of the pill postponed young women's marriage. It also postponed the beginning of childbearing and lowered birth rates. Women's lifetime fertility appears to have declined as well due to access to the pill (Ananat \& Hungerman 2007; Bailey 2006; Goldin \& Katz 2002; Guldi 2008).

The studies suggest that the contraception method adopted and used can have demographic significance in terms of fertility. However, the results obtained so far are inconsistent, and further research on the relationship between the modern contraceptives and the changes in fertility patterns is necessary. On the one hand, there are sociological and individual level psychological questions such as why people choose to control their fertility by using certain methods and not others or why they decide to adopt a new method. And on the other hand, there are demographic questions such as what happens to people's fertility when a new method is introduced or what kinds of relationships prevail between varying levels of contraceptive use, different contraceptive method mixes, and fertility patterns. Ideally, the viewpoints are brought together. A sociological depiction of social and cultural context of fertility limitation could be combined with quantitative fertility analysis. In this way it would be possible to estimate the effect of the contraceptive and specify the mechanism by which a certain fertility effect was generated - or why no effect was generated.

This article pursues clarification for some of the questions above by combining a sociological and a demographic perspective. In addition, the article will describe the early history of the pill in Finland. The focus will be on the diffusion of the pill and its relationships with fertility patterns. When, how, and by whom was the pill adopted? What happened to fertility after the introduction of the pill? The case of Finland is quite different from that of the United States, for example, because the availability of the pill or modern contraceptives in general has been intertwined with the construction of the extensive welfare state and its healthcare services.

\section{A theoretical approach on the role of contraceptives}

The general theoretical framework of this article comes from the second demographic transition theory. The theory suggests that whereas the first demographic transition was conditioned by declines in mortality, the changes in fertility patterns emerging in Western industrialized countries from the early 1960s onwards are related to the diffusion of new values emphasizing autonomy, individualism, and self-fulfillment (van de Kaa 1987; Lesthaeghe 1995). The theory is strongly based on Philippe Ariès' ideas (van de Kaa 2002, 4). 
Ariès (1980) separated two different views on life and offspring behind the fertility declines. The parents' concern to guarantee a good social and economic position for their children was a major motivational factor responsible for the first decline. But as the living standards rose quickly after the Second World War, adults became more interested in pursuing their own individual goals and self-fulfillment. Simultaneously their interest in their children's future became less central. Modern contraception technology was an indication of this changed mentality, but according to Ariès (ibid., 649-650) it did not cause the changes. Ariès' views on the modern contraceptives have been reflected in the SDT theory. The new contraceptive methods are by no means considered insignificant, but much more emphasis is placed on the cultural change that accompanied their introduction. Modern contraceptives increased the freedom of choice and made more complete fertility control possible. They were not just an indication of the change but also facilitated it (van de Kaa 1997).

The conclusions on the role of contraceptives during the fertility decline are not based on in-depth analysis. In order to explore the role of contraceptives more extensively, it is necessary to use a model of fertility behavior into which the two-way interaction between fertility patterns and the attributes of the new contraceptive methods in a specific context are incorporated (see Murphy 1993, 240). The significance of the different contraceptives can be outlined in this way by using Richard Easterlin's (1975) reformulation of the microeconomic theory of fertility.

Easterlin (ibid.) considers the balance between the demand and the supply of children in order to clarify the factors behind a certain level of fertility. In addition to this, he takes into account the costs of fertility control, which affect the total fertility equilibrium. If the supply of children is higher than their demand, the changing level of fertility control costs has a decisive effect on people's fertility behavior. The costs may be economic or psychic. The psychic costs depend on the attitudes prevailing in the social context, on the personal views related to contraception, and on the views on a specific method. In addition, the information on contraception techniques and on different methods, the availability of contraceptives, the prices of methods, and the selection of methods affect the perceived costs of fertility control. The introduction of the pill brought new kinds of costs and benefits related to the fertility control (ibid.; Easterlin \& Crimmins 1985).

As Easterlin's (1975) framework is combined with the SDT theory, it can be assumed that, due to the adoption of new values, the demand for children decreased. Simultaneously their supply remained at the same level as before. The introduction of modern contraceptives could have decreased the costs of fertility planning, thus easing the fertility control needed. Considering the pill, the most distinctive novelties were its strong connection with medicine and the wide acceptance given to it by doctors. The approval and control by the medical professionals both increased and decreased the 
economic and psychic costs of fertility limitation, depending on the viewpoint (Marks 2001, 116-117; Watkins 1998, 131). On the other hand, it is possible that the ease of use of the new innovative contraceptives was the propelling factor of fertility decline changing the balance between the demand and supply. It will be assessed in this paper, which one is the most likely scenario.

When studying the pill adoption in its contemporary context, the theory of the diffusion of innovations provides useful concepts to analyze the process. The diffusion is presented to be conditional on multiple factors, such as the structure of the social system under study. However, according to the theory there are certain general diffusion patterns. People can be divided into five groups in terms of the pace of innovation adoption: innovators, early adopters, early majority, late majority, and laggards. Those who adopt the innovation early are often more venturesome than others. They have usually more financial resources and better cognitive skills than do later adopters. Also the innovation itself has qualities that either help it to diffuse or make the diffusion more difficult. These characteristics can be related to its perceived benefits when it is compared with preceding solutions. The compatibility of an innovation with values, beliefs, preceding ideas, perceived needs, its ease of use, trialability, and observable results are also important factors affecting the diffusion process (Rogers 2003). These ideas can be taken advantage of when studying the pace of the pill diffusion and its first users.

\section{A short history of fertility control in Finland}

Before proceeding to the history of the pill it is worthwhile to examine briefly the general history of fertility limitation in Finland. Deliberate fertility limitation became widespread in Europe during the (first) demographic transition in the $19^{\text {th }}$ and early $20^{\text {th }}$ century. In Finland the transition began approximately in 1910. Compared to Western Europe the timing was quite late (Knodel \& van de Walle 1986, 394-395). Despite the transition, public attitudes towards fertility control remained negative well into the $20^{\text {th }}$ century (Sievers, Koskelainen \& Leppo 1974, 398).

One factor affecting the decline of the TFR was the growing proportion of non-married people, but also those engaged in sexual relationships changed their behavior (Lutz 1987, 470-471; Pitkänen 2003). People relied on abstinence, coitus interruptus, and abortions for controlling their fertility. Breastfeeding may also have had some significance in limiting the number of children. In addition, condoms and other mechanical contraceptives were sold and used to a small extent from the late $19^{\text {th }}$ century onwards, but they were probably difficult to obtain for the majority of people and their efficiency was questionable (Pitkänen 2003, 202, 205-206; Ritamies 2006, 176-183).

Declining fertility attracted a lot of attention in Finland. The predominant public opinion was strongly pronatalistic (Pitkänen 1988, 55). Anxiety reached its peak in the 1930s. At that time the TFR had dropped to low levels - its lowest being 2.27 in 1933 - and 
nationalistic worries surged (Statistics Finland 2011b). Contraception and especially abortion were usually criticized because they were considered unbeneficial for the nation (see Meskus 2003). However, despite the public condemnation, contraception was never legally abolished in Finland (Pitkänen 2003, 194).

Instead of prohibiting contraceptives, other measures were taken to avert depopulation. Legislative initiatives were channeled into supporting families (Pitkänen 1988, 69). In addition, Väestöliitto r.y., the Finnish Population and Family Welfare Federation (FPFWF, now the Family Federation), was founded in 1941. It was and has continued to be a central institute in shaping and fulfilling political goals related to reproduction, fertility control, and sexuality. The FPFWF was supported by the state but it did not work under any department of government. From 1947 onwards one of the tasks of the FPFWF was to give counseling related to sexual problems and family planning for people who were getting married or were already married (Rauttamo 1980). In addition to family planning work, the FPFWF soon got another closely related task. After the Act on Induced Abortion (82/1950) came into force - legalizing abortion for medical reasons - the FPFWF started to work on preventing abortions (Rauttamo 1980, 64).

The family planning counseling may appear to be in conflict with pronatalistic goals, but in the beginning it was expected that the possibility to conceive children at more suitable times would increase the total number of children per family. The main methods recommended by the doctors working at the FPFWF were spermicide and the diaphragm. Despite the pioneering work done by the FPFWF in the field of contraception, the contraceptives offered by the medical professionals were not widely used. Furthermore, doctors outside the FPFWF were not very eager to include contraception in their medical duties (Helén 1997, 241-242, 251, 255; Ritamies 2006, 196-197; Sievers et al. 1974, 409). In addition to their attitudes medical professionals did not necessarily have the education needed to provide contraceptives (Palolampi \& Leppo 1966, 56-57, 61). Thus, in the 1940s and 1950s it was still quite common that children were born without much planning (Nätkin 1994, 137).

Pronatalistic currents faded by the end of the 1950s, both in the work done by the FPFWF and in the public discussion. A temporary peak in the TFR took place after the war years in the 1940s, but the following decline did not any more cause extensive public anxiety. A new political atmosphere emphasized families' perspective and to some extent also that of the individual family members. The change was not as sudden and radical as it might appear here since, despite the shift in the viewpoint from population to family, the spheres of sexuality and reproduction were still targets of public control and guidance (Helén 1997, 233-238; Pitkänen 1988, 70; Statistics Finland 2011b). 


\section{The introduction of the pill}

The oral contraceptive pill was developed in the United States. Searle's Enovid was accepted and introduced into the market as a contraceptive in 1960 (Reed 1978, 364). Within a few years, the pill diffused into the English-speaking countries and Europe (Marks 2001, 183-185). In Finland, the first pill was introduced into the market in 1962 (Suomen tieteen historia 2000, 585). However, the first pill trials were already initiated by the FPFWF in 1961 (Väestöliitto 1961).

Even though the pill had received the approval of the Food and Drug Administration in the United States before entering the market, Finnish doctors approached it cautiously (Reed 1978, 364; Warpenius 1997, 53-58). As the FPFWF ruled in the field of family planning in the 1960s, its doctors scrutinized the pill carefully (Helén 1997, 249; e.g. Väestöliitto 1961). Despite the early caution, the pill was quickly accepted in the FPFWF (Turpeinen 1967, 13). However, this happened inside the framework of the counseling work of the FPFWF. The approval did not lead into a situation in which the pill would have been freely offered to everyone (Helén 1997, 250).

The lack of access to reliable contraception was one of the main themes in the sexual debate which broke out in 1965. The debate echoed similar discussions in other Western countries. It was initiated by students, in Finland especially by the students of medicine. The church, the educational authorities, doctors, and the FPFWF were all blamed for their conservative attitudes towards sexuality. The critics claimed that the prevailing views resulted in ignorance on sexuality and contraception, which, for example, caused illegal abortions to soar (see Taipale 1966).

The Finnish women's movement was also reviving in the mid-1960s. Yhdistys 9, The Equality Movement Association 9, campaigned, among other things, for the better availability of contraceptives in order to increase a woman's freedom to pursue sexual self-fulfillment (Jallinoja 1983, 128, 158, 172, 252). Some level of fertility control was also a precondition for a woman's chances to work outside the home (Julkunen 1994, 191). In Finland the proportion of working married women had started to grow in the urban areas in the 1950s. Women increasingly entered higher education and working life in the 1960s and 1970s (Hulkko 1979, 22; Jallinoja 1980, 234-235).

The public discussion from the mid-1960s onwards reflects the changed attitudes in Finnish society. As the SDT theory suggests, new values adopted were more liberal and individualistic than the preceding ones. Corresponding changes occurred also in family formation. In the early 1960s people still married young - in 1961-1965 the median age for a first marriage was 22.3 years for women and 24.1 for men - and the marriage rates were high. However, the number of divorces had already started to rise. Both the number of new marriages and the marriage rate began to decline from the early 1970s onwards. During the 1970s marriage started to shift to be later as well: in 
1976-1980 the median age for women entering their first marriage had risen to 23.3 years and 25.2 for men. Simultaneously cohabitation was becoming increasingly popular (Lindgren 1979; Miettinen 2005, 194; Statistics Finland 1967b, 53; Statistics Finland 1978, 60-62; see also van de Kaa 1997, 10).

It is specific for the Finnish context that the proponents of the new values emphasized the role and the activity of the state in ensuring that their goals could be met. They set various responsibilities for the public sector related to such fields as education and health (Taipale 1966). The discussion on gender roles, sexuality, and contraception began to turn into actions at the beginning of the 1970s. Many of the aims originally formulated by the social movements had become objectives of the rising welfare state. As mentioned, during the $20^{\text {th }}$ century individual's reproductive potential had been first viewed mainly from the perspective of the population and the nation, then from the viewpoint of the family. In the third phase, more attention was given to the individual and his or her individual wants and needs. Sexuality and the control of reproduction became increasingly viewed as important individual rights, which the state was assumed to guarantee and promote (Helén \& Yesilova 2003, 245-248). This also meant that the authorities were assumed to provide the services needed instead of non-governmental organizations (Ritamies 2006, 255).

Medical professionals were at the center of the changes related to fertility control. In approximately one decade a notable attitudinal shift took place among Finnish doctors. Many of them had adopted a rather liberal stance towards contraception by the end of the 1960s though still in 1968 doctors were more often willing to give family planning counseling when asked by married women (nine out of ten) than by those who were not married (two out or three). From the different methods available, the doctors already preferred the pill (Turpeinen 1968; Warpenius 1997). By the mid-1970s an individual's right to family planning counseling and to abortion had been consolidated in laws. The new Act on Induced Abortion (239/1970) - in which abortion was legalized on social grounds - and the Primary Health Care Act (66/1972) established the practices into the health care system of the welfare state. Both of these practices had become thoroughly medicalized.

When the Act on Induced Abortion (239/1970) came into force, the amount of legal abortions rose substantially. In 1973 more than 23,000 abortions were recorded (Stakes 2004). For comparison, in the same year the number of births was slightly below 57,000 (Statistics Finland 2011a). The rapid rise in abortion rates paved the way for the introduction of a law on contraception services. The activists of social movements, the FPFWF, authorities, and doctors were all able to agree that contraception was a better and more acceptable way to limit fertility than abortion. However, no separate law on contraception was ever enacted. Instead, contraception counseling was included in the Primary Health Care Act (66/1972) aimed to renew patchy primary health care. 
The responsibility to offer information on contraception and contraceptives for all residents of the municipality was given to the municipal health centers. In the health centers general practitioners and public health nurses performed the practical work (ibid.; Helén 1997, 249; Helén \& Yesilova 2003, 246-247; Kosunen \& Rimpelä 1997, 1199; Rintala 1995, 58-59; Warpenius 1997, 66-67).

The following extensive availability of the pill was closely related to doctors' approval of the pill and of contraception more generally. One important factor contributing to this was that the pill itself is a medical contraceptive. Doctors became more able to use their expertise in the field of fertility control. As in the United States, the ease of writing a prescription, compared with diaphragm fitting as performed earlier by some doctors, was probably also an advantage (Marks 2001, 121; Watkins 1998, 34-35). Simultaneously the change of generation was taking place among the Finnish doctors and the share of female doctors was increasing, perhaps resulting in more liberal attitudes (Riska 1987, 113; Suomen Lääkäriliitto 1972, 1428). For doctors, providing contraception was probably one way to reassert their position within the health care system. As stated, contraception was also seen as a response to high abortion rates. The change in the doctors' attitudes has been studied in detail by Katariina Warpenius (1997).

\section{The diffusion of the pill and fertility patterns}

Studying the diffusion of the pill between 1962 and mid-1970s quantitatively is challenging since there is hardly any numerical data available: this applies to the use of contraception in general as well. The first large-scale survey on topics related to sexuality and reproductive health was not completed until in 1971 (Sievers et al. 1974). Thus, the information on the use of pill in the 1960s is based on fragmentary data and estimations. The data used here is presented in Figures 1 and 2. In Figure 1, the changes in the number of the pill brands on the market are considered as indirect indicators of the trends in the use of the pill. The idea is that it would not have been profitable for the drug companies to keep their products on the market very long without user demand. In Figure 2, data on the use of the pill and previous research results are combined and transformed into the percentage of women using the pill during 1960-1976. The change in the percentages is tentatively represented in respect of the TFR. 


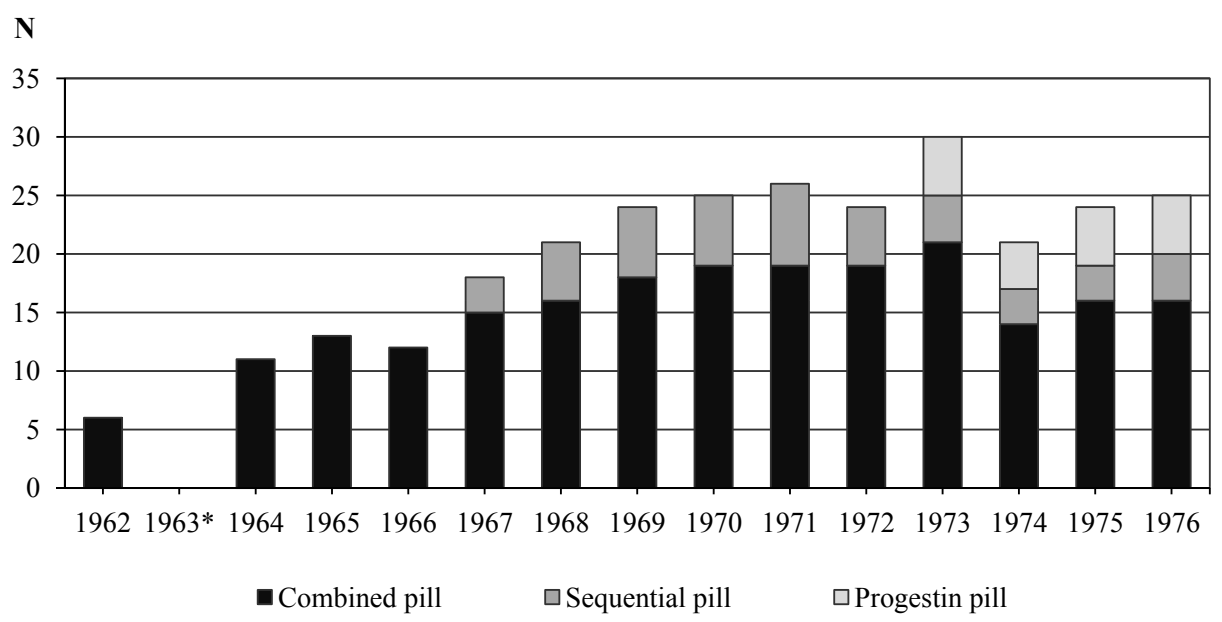

Figure 1. The number of the available pill brands according to the type of preparation in Finland during 1962-1976.

Source: Heinonen 1962; 1964-1969b; 1971-1972b; 1974a-1974b; 1975.

Note 1: * = No information available for 1963.

Note 2: Hormonal preparation Sarena is not included in the figures for 1969 because, even though it was listed among oral contraceptive pills, it was used to treat menopause.

Figure 1 is based on the information given in the Finnish drug catalogues called Remedia Fennica (see Heinonen 1962). As can be seen in Figure 1, the first pills introduced were combined contraceptive pills. They contained two different hormones, estrogen and progestin. Sequential pills became available in Finland in 1967. The sequential pills contained two hormones as well, but with an alternating dosage of hormones imitating the menstrual cycle. Progestin pills, which contained only one hormone, received their first selling permit in 1972, meaning that they were probably actually available in that year instead of 1973 as presented in Figure 1 (Lääkintöhallitus 1972, 2242). The number of brands on the market increased almost constantly between 1962 and 1973. Quick increases took place especially when new preparation types were introduced. During the period of 1962-1973 the only years, when the number of available brands was lower than in the preceding year, were 1966 and 1972. The number of brands started to increase again after 1974.

The explanation for the falls is that some pill brands were no longer considered suitable for contraception. After 1973 a rapid decrease in the number of the available combined pills took place. Some of the pill brands containing high hormone doses were withdrawn from the market in the 1970s and replaced by preparations with lower doses as the harmful side effects of the pills were becoming more evident to the authorities and the pharmaceutical industry (Hirvonen 1972, 251; Willamo 1972). Also the number of sequential pills on the market decreased to a small extent during the period under 
study. Due to suspicions of an increased risk of cancer the sequential pills were not recommended any more in the 1980s and they were completely removed from the market by the end of the 1990s (Kivijärvi 1997, 1170; Lähteenmäki 1987, 525-526, 528; Robertson 1990, 131).

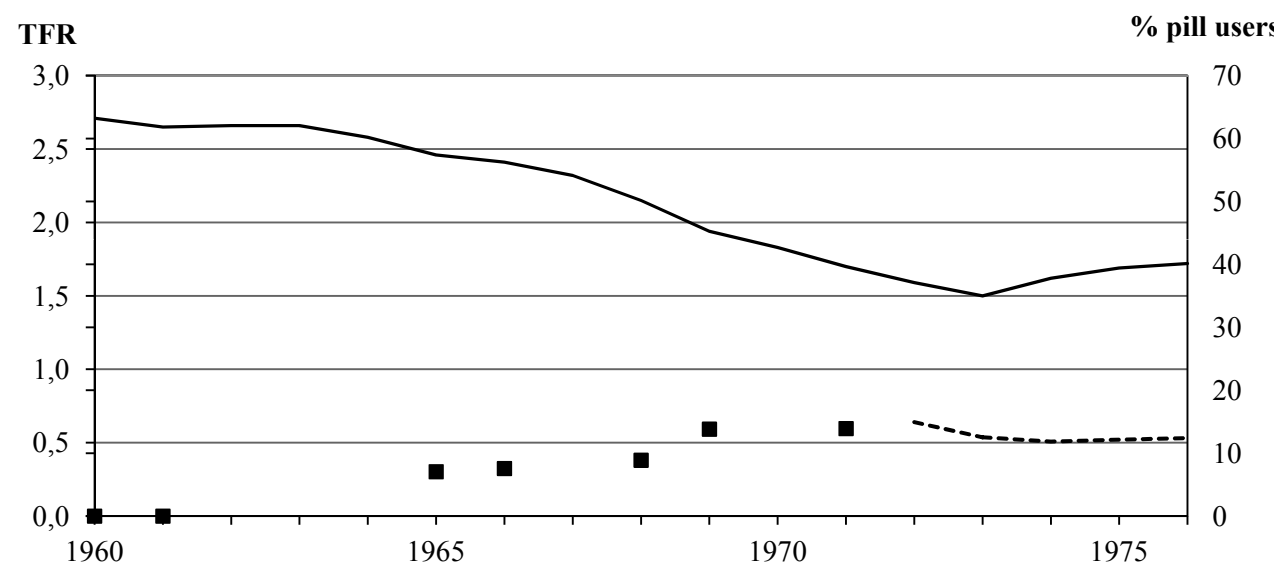

Figure 2. The total fertility rate (TFR) and the percentage of women aged 15-44 using the pill in Finland during 1960-1976.

Source: Auvinen 1991, 226; Brunila 1966, 1307; Hirvonen 1972, 250; Lääkintöhal $\neg$ litus 1977; Nyman 1971, 9; Sievers et al. 1974, 417; Statistics Finland 1967a, 10; Statistics Finland 1969, 14; Statistics Finland 1973, 44; Statistics Finland 1975, 36; Statistics Finland 2010; Statistics Finland 2011b; Turpeinen 1967, 12.

Note 1: The continuous line represents the TFR. The squares indicate the percentage of users based on estimations and contemporary studies. The dash line indicates the percentage of users based on sales figures.

Note 2: It is estimated that in 1960 there were no users and that in 1961 the number was still practically zero. The percentage of users for the later years has been calculated by dividing the number of users by the mid-year population of women aged 15 to 44 . If the number obtained from the source is given to other age groups than those aged 15 to 44, the number of those users aged 15 to 44 has been calculated on the basis of the population structure if possible. Some small age groups have been left out from the calculations mainly because the data was not collected on them (e.g. in Sievers et al. 1974 the question on the use of the pill was not asked from those younger than 18 years of age). If there are several figures available for one year, their average has been used. After 1971, only sales figures are used since they are considered more reliable. Sales figures were reported as the number of packages (a dose of one month) sold in 1972-1976. The figure was divided by 12 and then by the mid-year population of fertile women.

Note 3: Compare the figure with a similar one presented by Henri Leridon (2006).

Figure 2 presents a more exact picture on the diffusion of the pill. Several sources have been used in order to calculate the number of females aged 15 to 44 using the pill. After calculating the amount of users, the figure has been divided by the mid-year population of women aged 15 to 44 . Sources and details are described below the figure. Based on the figure, the pill diffused quite slowly at first. Its use took off after the mid-1960s. The peak in women using the pill in the study period was most likely reached around 1969 to 1972. In 1969 the estimated number of users was about 14 percent and in 1972 approximately 15 percent. The percentage of women using the pill started to decline after the peak period. There are probably two major reasons for the decline. The first 
one was the worried atmosphere related to the research results confirming that the pill did increase the risk of thrombotic disease (see Marks 2001, 138-147; Murphy 1993). The other one is that a potential alternative for the pill was developed. In 1973 a new IUD model made out of copper was introduced in Finland (Suomen Lääkärilehti 1973, 414). Hormonal IUDs also became available in 1976 (Luukkainen \& Nilsson 1987, 572). The IUDs diffused first among slightly older women. The IUDs had not gained much popularity by the early 1970 s, but in 1977 more than one fourth $(27.9 \%)$ of married women aged 18 to 44 was using it. Simultaneously the popularity of the pill had decreased by nearly half to 11.3 percent (Riihinen, Pulkkinen \& Ritamies 1979, 35, 37; Sievers et al. 1974, 417, 451-452).

Based on Figure 2, it is tempting to suggest that during the early years of the pill there was a reverse connection between the TFR and the level of pill users. There was a rapid and continuous decline in the TFR just after 1963 (TFR 2.66) until 1973, when TFR reached its all-time nadir sinking to 1.50 . In the 1990s and at the beginning of the $21^{\text {st }}$ century the TFR has been fluctuating around 1.80 (Statistics Finland 2011b). The simple Pearson's correlation, based on an assumption on a linear connection between the percentage of users during 1965-1976 (the available data range) and the TFR, is very strong, $-0,87$ (pvalue 0,001 ). Yet there is not enough reliable data to prove that this decline would have been caused by the introduction of the pill. Data that are more complete and accurate would be needed on the use of the pill, the changing user levels of other contraceptives, and on abortion rates. One should also include other factors generally considered to affect fertility levels in order to separate out the effect of the new technology.

However, the fertility patterns possibly related to the introduction of the pill can be further studied by viewing the age-specific fertility rates (Figure 3). Fertility declined in every age group between the 1950s and the 1980s but the timing and the scale were different depending on the age group. Up to the latter half of the 1960s, the fertility levels of young women remained stable and those of women aged 25 or more declined. Between the periods 1961-1965 and 1971-1975 fertility declined rapidly in almost all age groups. Those aged 15 to 19 were an exception, since their fertility did not start to decline until the early 1970s. During the latter half of the 1970s the fertility of women aged 25 to 39 increased slightly. 


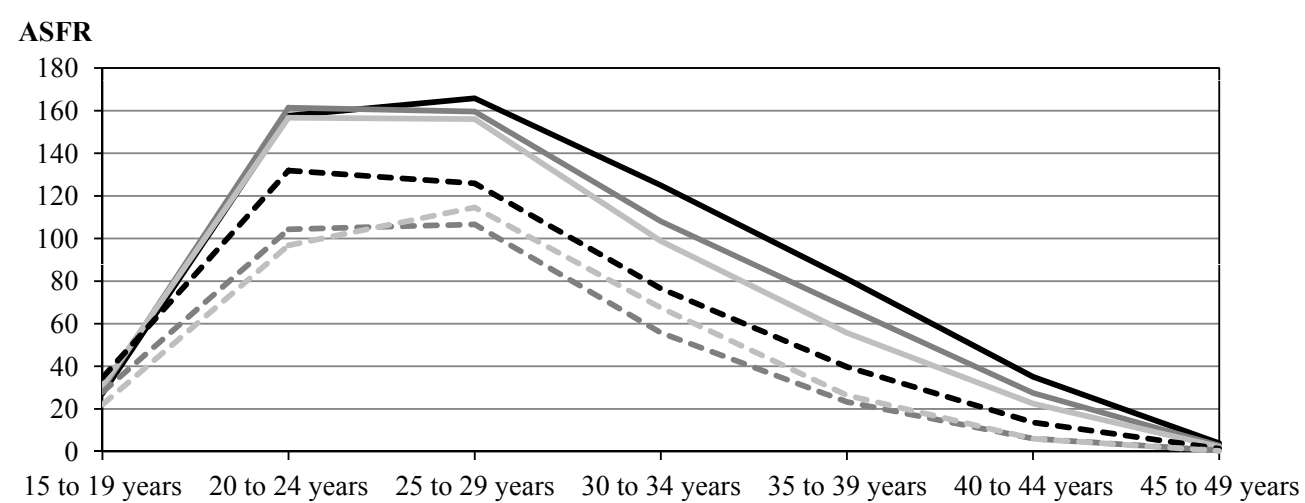

$\longrightarrow 1951-55 \longrightarrow 1956-60 \longrightarrow 1961-65--1966-70 \quad--1971-75 \quad---1976-80$

Figure 3. The age-specific fertility rates (ASFRs) of Finnish women in five-year age groups during 1951-1980.

Source: Mäenpää \& Hellanto 2007, 329.

The period measures give only partial information on changes in the fertility behavior. A more complete picture is achieved by studying the fertility of the relevant cohorts. Both timing of births and completed fertility have to be considered. It appears that changes in timing explain the development of the TFR to very low levels in the 1960s and early 1970s. The cohorts born in 1937 and after that increasingly started to postpone childbearing. This can also be seen as a shift in the median age of a mother at first birth: it was 23.25 years in 1961-1965 and 25.18 in 1976-1980. During the same period cohorts born in 1923-1936 stopped having children at an earlier phase of life than the preceding cohorts. The overlapping of these changes resulted in the very low TFR (Miettinen 2005, 193; Notkola 1995).

Completed fertility of the cohorts born in the early 1920s was 2.6 children. These cohorts were the last ones having no or very limited access to the pill. By contrast, women born from 1945 to 1955 - who had access to the pill almost throughout their entire fertile period - had on average 1.8-1.9 children. The fertility of those born 1923-1936 declined when they were over 30. As the pill diffused very slowly at first, it is unlikely that it would have been responsible for a notable decline of fertility in the oldest age groups. In the cohorts born before the mid-1950s, the decline took place among women in their twenties. In later cohorts the decline shifted further to younger age groups, those in their early twenties and aged 15 to 19 . The potential effect of the pill in the younger cohorts is considerable, but it must be kept in mind that both the new law on abortion and the introduction of the IUD also fell in their reproductive years. An exact estimate of the cohort effect is beyond the scope of this article. However, the decline in cohort fertility has been quite steady. This suggests 
that the effect of the pill was not that revolutionary from the viewpoint of final fertility outcome. The change in fertility had already been underway and the pill was probably one contributing factor (Notkola 1995).

The significance of the pill was probably the largest for young women. The fertility of those in their 20s and early 30s declined notably between the early 1960s and the 1970s (ibid.). Based on contemporary studies it appears that the first users of the pill were quite young. In addition to that they were educated and living in urban areas. They were also quite likely married. In a study completed in 1968, based on a sample of drugs sold in one day, the percentage of users of the pill was highest in southern Finland. According to a separate survey it is likely that the highest user percentage could be found in the region of Helsinki. In this survey the user percentage was highest in the age group of those aged 25 to 34 (17.4\%) and the second highest in the group of 18-24-year-olds (13.9\%). Considering marital status, the largest percentage of users could be found among those who were married, 14.4\% (Nyman 1971, 9-11).

At the beginning of the 1970s, according to a more extensive study, the age patterns were quite similar; though it seems that the use of the pill had increased especially in the youngest age groups. The pill was especially used by young women aged 18 to 20 (15\%), 21 to $24(29 \%)$, and 25 to $29(18 \%)$. Women aged 40 to 44 used the pill less often $(6 \%)$. In this age group the percentage of those who used withdrawal or could not have children was much larger than in the younger age group. At this point the social and educational differences were small or inconsistent in terms of the innovation diffusion. Nevertheless, among those who had taken the pill at some point of their life, the situation was different. Women belonging to higher social classes, having higher education and income (family income), and living in southern cities were more likely to have used the pill than other women. It can be assumed that the differences in the use of the pill between the groups of the innovation adopters had diminished over time while the women with characteristics associated with the most innovative groups having better resources (such as more education) led the adoption in the 1960s. Innovators and early adopters had perhaps already started to use the IUD at the beginning of the 1970s. At least part of the late majority and laggards still used more traditional methods (Rogers 2003; Sievers et al. 1974, 417, 420, 451-452; see also Nyman 1971, 11).

\section{Conclusions}

The pill became available in Finland in 1962. The peak of its use under the study period was achieved around the turn of the 1960s and 1970s. It is important to note that the user levels did not climb extremely high at that time: no more than to 15 percent of women aged 15 to 44 . For comparison, at the beginning of the $21^{\text {st }}$ century one fourth of women aged 18 to 44 used the pill (Kosunen et al. 2004, 54). The pill has been a popular contraceptive method also among younger women. In 2003 approximately 21 
percent of 16-year-olds used the pill (Hassani, Kosunen \& Rimpelä 2006, 651). However, women aged 35 or more preferred the IUD (Kosunen et al. 2004, 54).

It does not seem justified to state that the pill caused a revolutionary fertility change. Yet major changes in fertility and fertility-related behavior did occur in the 1960s and the 1970s simultaneously with the introduction of the pill. The TFR declined quickly since younger women postponed childbearing and older women stopped childbearing earlier. The completed cohort fertility of those women going through their fertile period in the 1960s and the 1970s decreased notably compared to the previous cohorts. The decline seems to be a result of multiple factors, such as an easier access to abortion. It was not a phenomenon caused solely by the introduction of the pill (Notkola 1995; Ruokolainen \& Notkola 2007, 78).

It appears that especially young married women took advantage of the pill to postpone the onset of childbearing. This partly affected the decline of the TFR. Perhaps the most central change following the introduction of the pill was that the interconnection between a sexual union and childbearing was loosened (Ruokolainen \& Notkola 2007, 96-97). It seems that many couples had wished for the possibility to postpone childbearing and to wait longer. Between 1971 and 1977 parents became much more satisfied with the timing of the children's births as abortion and modern contraceptives became more easily available. The optimal time between marriage and the first birth was considered to be 2.2 years in the 1970 s. In practice, the time was only 1.3 years still in the latter half of the 1970 s and $38 \%$ of women who got married were pregnant (Riihinen et al. 1979, 39-40). It is, however, likely that marriages became increasingly postponed until a pregnancy occurred.

The changes in fertility patterns were accompanied by many social and cultural changes. The value changes during the 1960s and the 1970s fit quite well into the framework of the SDT theory. One of the most relevant changes was that women, including married women, entered more often into higher education and working life. These kinds of aims provide a plausible motivation for the postponement of childbearing. The use of the pill began in groups belonging to higher social classes and having more education, but it had spread wider by the early 1970s. At this time the women that led in pill use had perhaps already changed their contraception method to the IUD.

As the pill first became available for growing numbers of women during the late 1960s and early 1970s, it provided them with a very effective way to control their fertility. The pill probably offered a great deal of confidence to its user. It was also considered to be easier to use and more comfortable than other contraceptives, the IUD being an exception (Sievers et al. 1974, 434). At least before the public discussion on its sideeffects the pill was probably considered to have a notable advantage over the older solutions. The comparison with abortion further increased the acceptability of the pill. Moreover, although contraceptives had been viewed negatively for a very long 
time, the approval of doctors made the pill more acceptable. Simultaneously public attitudes towards contraception loosened. In practice, the municipal health centers of the welfare state made the prescriptions more attainable.

In general, the pill probably decreased the costs of fertility regulation. Within Easterlin's (1975) framework, it can be suggested that the costs of fertility control lowered notably. Yet the decrease was restricted, firstly, because the lowering of costs was hindered by the limited access to the pill and, secondly, because soon after its wider availability negative publicity made the pill less attractive. The motivation to limit fertility appears to have been there already. However, new opportunities, such as combining a partnership with a career, have probably further increased the motivation to control fertility efficiently. Controlling fertility in a certain phase of life appears to have been the central function of the pill, not so much the recalibrating of the total number of children. Yet the postponement facilitated by the pill may have lead indirectly to lower completed fertility since the supply of children is likely to be more limited among older women (van de Kaa 1997, 10).

The conclusions of this article come close to those of the SDT theory: modern contraceptives were not the trigger for the changes. However, they were a necessary condition to the scale and nature of the changes in fertility patterns. They brought about a notable qualitative change in the field of reproductive control, which facilitated social changes. It would be interesting to study the adoption of modern contraceptives further. Unfortunately, the data on the pill in the Finnish context has proved to be difficult to obtain. However, the attempt to combine a more complete quantitative analysis with a detailed depiction of the historical context could be fruitful concerning some other country.

\section{References}

Ananat, Elizabeth Oltmans and Daniel M. Hungerman. 2007. The power of the pill for the next generation. NBER Working Paper, No. 13402. Cambridge: National Bureau of Economic Research.

Ariès, Philippe. 1980. Two successive motivations for the declining birth rate in the West. Population and Development Review 6(4): 645-50.

Auvinen, Riitta. 1991. Äitiyssuojelusta perhekasvatukseen. [From maternal protection to family education.] In: Perheen puolesta: Väestöliitto 1941-1991, edited by Ritva Taskinen, pp. 205-42. Helsinki: Otava, Väestöliitto.

Bailey, Martha J. 2006. More power to the pill: the impact of contraceptive freedom on women's life cycle labor supply. Quarterly Journal of Economics 121(1): 289-320.

Brunila, Tom. 1966. Ehkäisytabletit ja muovikierukat syntyvyyden säännöstelyssä [Contraception pills and plastic IUDs in birth control]. Suomen Lääkärilehti 21(15): 1307-12.

Cliquet, R. L. 1991. The second demographic transition: fact or fiction? In: Population Studies, Vol. 23. Strasbourg: Council of Europe. 
Coleman, David. 2004. Why we don't have to believe without doubting in the "Second Demographic Transition": some agnostic comments. Vienna Yearbook of Population Research 2004: 11-24.

Easterlin, Richard A. 1975. An economic framework for fertility analysis. Studies in Family Planning 6(3): 54-63. Easterlin, Richard A. and Eileen M. Crimmins. 1985. In: The fertility revolution: a supply-demand analysis. Chicago: The University of Chicago Press.

Goldin, Claudia and Lawrence F. Katz. 2002. The power of the pill: oral contraceptives and women's career and marriage decisions. Journal of Political Economy 110(4): $730-70$.

Guldi, Melanie. 2008. Fertility effects of abortion and birth control pill access for minors. Demography, 45(4): 817-27.

Hassani, Kobra F., Elise Kosunen, and Arja Rimpelä. 2006. The use of oral contraceptives among Finnish teenagers from 1981 to 2003. Journal of Adolescent Health 39(5): 649-55.

Hayashi, Aiko. 2004. Japanese women shun the pill. CBSNews.com. [Online.] 20 August 2004. [Cited 3 September 2011.] Available from: $\leq$ http://www.cbsnews. com/stories/2004/08/20/ health/main637523.shtml $>$.

Heinonen, Olli P. 1962. Remedia Fennica 1962. Helsinki: Fennia.

—. 1964. Remedia Fennica 1964. Pitäjänmäki: Remedia Fennica.

—. 1965. Remedia Fennica 1965. Helsinki: Remedia Fennica.

—. 1966. Remedia Fennica 1966. Helsinki: Remedia Fennica.

—. 1967. Remedia Fennica 1967. Helsinki: Remedia Fennica.

—. 1968. Remedia Fennica 1968. Helsinki: Remedia Fennica.

—. 1969a. Remedia Fennica 1969. Helsinki: Remedia Fennica.

—. 1969b. Remedia Fennica 1970. Helsinki: Remedia Fennica.

—. 1971. Remedia Fennica 1971. Helsinki: Remedia Fennica.

—. 1972a. Remedia Fennica 1972. Helsinki: Remedia Fennica.

—. 1972b. Remedia Fennica 1973. Helsinki: Remedia Fennica.

—. 1974a. Remedia Fennica 1974. Helsinki: Remedia Fennica.

—. 1974b. Remedia Fennica 1975. Helsinki: Remedia Fennica.

—. 1975. Remedia Fennica 1976. Helsinki: Remedia Fennica.

Helén, Ilpo. 1997. Äidin elämän politiikka: naissukupuolisuus, valta ja itsesuhde Suomessa 1880-luvulta 1960-luvulle. [Politics of mother's life: female gender, power, and self-relation in Finland from the 1880s to the 1960s.] Helsinki: Gaudeamus.

Helén, Ilpo and Katja Yesilova. 2003. Vietti, väestö ja valinta: seksuaaliterveyden kerrostumat Suomessa. [Instinct, population, and choice: the layers of sexual health in Finland.] In: Kansalaisuus ja kansanterveys, edited by Ilpo Helén and Mikko Jauho, pp. 233-59. Helsinki: Gaudeamus.

Hirvonen, Erkki. 1972. Ehkäisytabletit ja tromboemboliariski. [Contraceptive pills and the risk of thromboembolic disease.] Suomen Lääkärilehti 27(3): 250-2.

Hulkko, Jouko. 1979. Population development and population policy in Finland. Yearbook of Population Research in Finland 17: 15-31. 
Jallinoja, Riitta. 1980. Miehet ja naiset. [Men and women.] In: Suomalaiset: yhteiskunnan rakenne teollistumisen aikana, edited by Tapani Valkonen, Risto Alapuro, Matti Alestalo, Riitta Jallinoja, and Tom Sandlund, pp. 222-50. Helsinki: Werner Söderström Osakeyhtiö.

—. 1983. Suomalaisen naisasialiikkeen taistelukaudet: naisasialiike naisten elämäntilanteen muutoksen ja yhteiskunnallis-aatteellisen murroksen heijastajana. [The struggle periods of the Finnish women's movement: the women's movement as a reflection of the change in women's situation of life and the socio-ideological change.] Helsinki: Werner Söderström Osakeyhtiö.

Julkunen, Raija. 1994. Suomalainen sukupuolimalli - 1960-luku käänteenä. [The Finnish gender model - the 1960s as a turning point.] In: Naisten hyvinvointivaltio, edited by Anneli Anttonen, Lea Henriksson, and Ritva Nätkin, pp. 179-201. Tampere: Vastapaino.

van de Kaa, Dirk J. 1987. Europe's second demographic transition. Population Bulletin 42(1).

- 1997. Options and sequences: Europe's demographic patterns. Journal of the Australian Population Association 14(1): 1-29.

-. 2002. The idea of a Second Demographic Transition in industrialized countries. Paper presented at The Sixth Welfare Policy Seminar of the National Institute of Population and Social Security, Tokyo, 29 January 2002.

Kivijärvi, Anneli. 1997. Löytyykö sopiva pilleri? [Can a suitable pill be found?] Duodecim 113(12): 1169-73.

Knodel, John and Etienne van de Walle. 1986. Lessons from the past: policy implications of historical fertility studies. In: The decline of fertility in Europe: the revised proceedings of a conference on the Princeton European fertility project, edited by Ansley J. Coale and Susan Cotts Watkins, pp. 390-419. Princeton: Princeton University Press.

Kosunen, Elise and Matti Rimpeläinen. 1997. Perhesuunnittelun palvelujärjestelmä. [The service organization of family planning.] Duodecim 113(12): 1198-202.

Kosunen, Elise, Sinikka Sihvo, Minna Nikula, and Elina Hemminki. 2004. Raskauden ehkäisy. [Prevention of pregnancy.] In: Lisääntymisterveys Suomessa, edited by Päivikki Koponen and Riitta Luoto, pp. 54-61. Publications of the National Public Health Institute B5/2004. Helsinki: Kansanterveyslaitos.

Leridon, Henri. 2006. Demographic effects of the introduction of steroid contraception in developed countries. Human Reproduction Update 12(5): 603-16.

Lesthaeghe, Ron. 1995. The second demographic transition in Western countries: an interpretation. In: Gender and family change in industrialized countries, edited by Karen Oppenheim Mason and An-Magritt Jensen, pp. 27-62. Oxford: Oxford University Press.

Lindgren, Jarl. 1979. A new phenomenon: cohabitation outside marriage. Yearbook of Population Research in Finland 17: 53-7.

Lutz, Wolfgang. 1987. Factors associated with the Finnish fertility decline since 1776. Population Studies 41(3): 463-82.

Luukkainen, Tapani and Carl G. Nilsson. 1987. Hormonikierukka. [Hormonal IUD.] Duodecim 103(9): 572-7. 
Lähteenmäki, Pekka. 1987. Hormonaalisen ehkäisyn hyödyt ja riskit. [The benefits and risks of hormonal contraception.] Duodecim 103(9): 525-31.

Lääkintöhallitus. 1972. Lääkintöhallituksen tiedotuksia. [Announcements of the National Board of Health.] Suomen Lääkärilehti 27(24): 2242-5.

—. 1977. E-pillereiden myynti Suomessa VV 1972-1976: tilastoja farmaseuttisten erikoisvalmisteiden / lääkevalmisteiden kulutuksesta ja myynnistä 1968-1988. [The sale of contraceptive pills in Finland 1972-1976: statistics on the consumption and sale of pharmaceutical special preparations / drug preparations 1968-1988.] Lääkintöhallituksen apteekkitoimisto. Kansallisarkisto.

Marks, Lara V. 2001. Sexual chemistry: a history of the contraceptive pill. New Haven: Yale University Press.

Meskus, Mianna. 2003. Väestön elinvoima ja tahallinen keskenmeno: raskauden keskeyttämisen politisoituminen 1900-luvun alun Suomessa. [Population vitality and induced miscarriage: politicization of abortion in the early 20th century Finland.] In: Kansalaisuus ja kansanterveys, edited by Ilpo Helén and Mikko Jauho, pp. 211-32. Helsinki: Gaudeamus.

Miettinen, Anneli. 2005. Population Data on Finland 1900-2004. Yearbook of Population Research in Finland 41: 191-8.

Murphy, Michael. 1993. The contraceptive pill and women's employment as factors in fertility change in Britain 1963-1980: a challenge to the conventional view. Population Studies 47(2): 221-43.

Mäenpää, Elina and Jari Hellanto. 2007. Liitetaulukot: Suomen väestöä kuvaavia lukusarjoja. [Appendix tables: numerical series on the population of Finland.] In: Suomen väestö, edited by Seppo Koskinen, Tuija Martelin, Irma-Leena Notkola, Veijo Notkola, Kari Pitkänen, Marika Jalovaara, Elina Mäenpää, Anne Ruokolainen, Markku Ryynänen, and Ismo Söderling, pp. 323-37. Helsinki: Gaudeamus.

Notkola, Irma-Leena. 1995. Cohort fertility changes and period fertility in 1960-1990 in Finland. Yearbook of Population Research in Finland 32: 19-31.

Nyman, Kauko. 1971. Ehkäisytablettien käyttö Suomessa vuonna 1968. [The use of contraceptive pills in Finland in 1968.] A publication by the Social Insurance Institution, E 33. Helsinki: Kansaneläkelaitoksen Sosiaaliturvan tutkimuslaitos.

Nätkin, Ritva. 1994. Väestöpolitiikka, abortti ja äitiys: hyvinvointivaltion ammattilaisten ja naisten suhteen tarkastelua. [Population policy, abortion, and motherhood: reviewing the relationship between the professionals of the welfare state and women.] In: Naisten hyvinvointivaltio, edited by Anneli Anttonen, Lea Henriksson, and Ritva Nätkin, pp. 129-55. Tampere: Vastapaino.

Palolampi, Eero and Kimmo Leppo. 1966. Suunnittelematonta perhesuunnittelua. [Unplanned family planning.] In: Sukupuoleton Suomi, edited by Ilkka Taipale, pp. 52-64. Helsinki: Tammi.

Pasila, Aura. 2010. Tieteellinen, turvallinen ja sovinnainen uutuus: suomalaisille lääkäreille suunnattu ehkäisypillerimainonta vuosina 1962-1973. [A scientific, safe, and conventional innovation: the contraceptive pill advertising aimed at Finnish doctors]. Master's thesis. University of Helsinki: Department of Social Research. 
Pitkänen, Kari. 1988. Väestöntutkimus ja yhteiskunta: suomalaisen väestöntutkimuksen historia 1700-luvulta noin vuoteen 1950. [Demography and the society: the history of Finnish population research, 1750-1950.] Publications of the Finnish Demographic Society, vol. 11. Helsinki: Suomen Väestötieteen Yhdistys.

- 2003. Contraception in late nineteenth- and early twentieth-century Finland. Journal of Interdisciplinary History 34(2): 187-207.

Rauttamo, Mari. 1980. Valistusjärjestöstä toimeenpanevaksi väestöpoliittiseksi elimeksi: Väestöliiton syntyhistoria ja liiton toimintaa vuosina 1941-1960. [From a counseling organization to an active organ of population policy: the early history and work ofthe Finnish Population and Family Welfare Federation from 1941 to 1960]. Helsinki: Väestöliitto.

Reed, James. 1978. From private vice to public virtue: the birth control movement and American society since 1830. New York: Basic Books.

Riihinen, Olavi, Aimo Pulkkinen, and Marketta Ritamies. 1979. The realization of family planning in Finland with particular reference to the development in the 1970s. Yearbook of Population Research in Finland 17: 32-44.

Rintala, Taina. 1995. Medikalisaatioja sosiaali-ja terveydenhuollon palvelujärjestelmän rakentuminen 1946-1991. [Medicalization and the construction of the social and health service system 1946-1991.] Research reports, National Research and Development Centre for Welfare and Health, 54. Helsinki: Stakes.

Riska, Elianne. 1987. Läkärprofessionens förändrande ställning: en fallstudie av kvinnliga läkare i Finland. [The changing status of the medical profession: a case study on female doctors in Finland.] Sosiaalilääketieteellinen Aikakauslehti 24(2): 105-15.

Ritamies, Marketta. 2006. Sinappikylvystä ehkäisypilleriin: suomalaisen perhesuunnittelun historia. [From mustard bath to contraception pill: the history of Finnish family planning.] Publications of the Population Research Institute, D 44. Helsinki: Väestöliitto.

Robertson, William H. 1990. An Illustrated history of contraception: a concise account of the quest for fertility control. Carnforth: The Parthenon Publishing Group.

Rogers, Everett M. 2003. Diffusion of innovations. New York: Free Press.

Ruokolainen, Anne and Irma-Leena Notkola. 2007. Hedelmällisyys. [Fertility.] In: Suomen väestö, edited by Seppo Koskinen, Tuija Martelin, Irma-Leena Notkola, Veijo Notkola, Kari Pitkänen, Marika Jalovaara, Elina Mäenpää, Anne Ruokolainen, Markku Ryynänen, and Ismo Söderling, pp. 77-113. Helsinki: Gaudeamus.

Sievers, Kai, Osmo Koskelainen and Kimmo Leppo. 1974. Suomalaisten sukupuolielämä. [Finnish sex life.] Helsinki: Werner Söderström Osakeyhtiö.

Stakes. 2004. Pohjoismaiset raskaudenkeskeytystilastot. [Nordic statistics on induced abortions.] [Online.] Statistical summary 32. [Cited 12 July 2010.] Available from: $<$ http://www.stakes.fi/NR/rdonlyres/304830FC-E883-4767-9827-17132471106C/0 /Tt32 04.pdf $>$.

Statistics Finland. 1967a. Väestönmuutokset 1965. [Vital statistics 1965.] Official Statistics of Finland, VI A 125. Helsinki: Tilastokeskus.

—. 1967b. Suomen tilastollinen vuosikirja 1966. [Statistical yearbook of Finland 1966.] Official Statistics of Finland. Helsinki: Tilastokeskus. 
—. 1969. Väestönmuutokset 1966. [Vital statistics 1966.] Official Statistics of Finland, VI A 127. Helsinki: Tilastokeskus.

—. 1973. Väestönmuutokset 1970. [Vital statistics 1970.] Official Statistics of Finland, VI A 132. Helsinki: Tilastokeskus.

—. 1975. Väestönmuutokset 1971. [Vital statistics 1971.] Official Statistics of Finland, VI A 133. Helsinki: Tilastokeskus.

—. 1978. Suomen tilastollinen vuosikirja 1977. [Statistical yearbook of Finland 1977.] Official Statistics of Finland. Helsinki: Tilastokeskus.

- 2010. Väestö iän (5-v.) ja sukupuolen mukaan koko maa 1865-2009. [Population according to age (5-year) and gender in the whole country 1865-2009.] [Online.] PX-Web Statfin database. [Cited 29 July 2010.] Available from: $<$ http://pxweb2. stat.fi/Dialog/varval.asp?ma $=120$ vaerak tau 105 fi\&ti $=\mathrm{V} \% \mathrm{E} 4 \mathrm{est} \% \mathrm{~F} 6+\mathrm{i} \% \mathrm{E} 4 \mathrm{n}+$ $\% 285 \% 2 \mathrm{Dv} \% 2 \mathrm{E} \% 29+$ ja + sukupuolen + mukaan + koko + maa $+1865+\% 2 \mathrm{D}+2009 \& \mathrm{p}$ ath $=$. ./Database/StatFin/vrm/vaerak/\&lang=3\&multilang=fi $>$.

- 2011a. Live births by gender 1751-2010. [Online.] PX-Web Statfin database. [Cited 31 May 2011.] Available from: $<$ http://pxweb2.stat.fi/database/StatFin/vrm/ synt/synt en.asp $>$.

-. 2011b. Total fertility rate 1776-2010. [Online.] PX-Web Statfin database. [Cited 31 May 2011.] Available from: <http://pxweb2.stat.fi/database/StatFin/vrm/synt/ synt en.asp $>$.

Statute Book of Finland 1950, No. 82. Laki raskauden keskeyttämisestä. [Act on Induced Abortion.]

Statute Book of Finland 1970, No. 239. Laki raskauden keskeyttämisestä. [Act on Induced Abortion.]

Statute Book of Finland 1972, No. 66. Kansanterveyslaki. [Primary Health Care Act.]

Suomen Lääkärilehti. 1973. Kupari-T markkinoille Suomessa. [Copper T introduced to the Finnish market.] Suomen Lääkärilehti 28(6): 414-6.

Suomen Lääkäriliitto. 1972. Suomen Lääkäriliiton hallituksen toimintakertomus vuodelta 1971. [Annual report of the board of the Finnish Medical Association for the year 1971.] Suomen Lääkärilehti 27(14): 1411-35.

Suomen tieteen historia: 3, luonnontieteet, lääketieteet ja tekniset tieteet. [History of Finnish science: 3, natural sciences, medicine, and technical sciences.] 2000. Edited by Päiviö Tommila and Allan Tiitta. Porvoo: WSOY.

Taipale, Ilkka, editor. 1966. Sukupuoleton Suomi. [Sexless Finland.] Helsinki: Tammi.

Turpeinen, Kaisa. 1967. Väestöliiton kansanterveystyö v. 1966. [The public health work of the Finnish Population and Family Welfare Federation in 1966.] Avioliitto ja lääkäri 18(1): 3; 12-3.

—. 1968. Tiedustelu lääkäreiden suhtautumisesta ehkäisyneuvontaan. [An enquiry concerning the doctors' attitudes towards birth control counseling.] Lääkäri ja yhteiskunta 19(4): 65-7.

Väestöliitto. 1961. XXI toimintavuosi. [The XXI year of activity.] Helsinki: Väestöliitto. 
Warpenius, Katariina. 1997. Asiantuntijavalta, riskit ja yksilöllistyminen: tutkielma lääketieteen asiantuntijoiden raskauden ehkäisykeskustelusta Suomessa vuosina 1960-74. [The professional power, risks, and individualization: a thesis on the medical professionals' birth control discussion in Finland in years 1960-74.] Master's thesis. University of Helsinki: Department of Sociology.

Watkins, Elizabeth S. 1998. On the pill: a social history of oral contraceptives, 1950-1970. Baltimore: The Johns Hopkins University Press.

Watkins, Susan C. 1986. Conclusions. In: The decline of fertility in Europe: the revised proceedings of a conference on the Princeton European fertility project, edited by Ansley J. Coale and Susan C. Watkins, pp. 420-49. Princeton: Princeton University Press.

Willamo, Harri. 1972. Uusi Lyndiol: kirje Organonilta. [New Lyndiol: a letter from Organon.] The Ephemera Collection of the National Library of Finland.

Østby, Lars. 1989. The diffusion of modern contraception in Norway and its consequences for the fertility pattern. European Journal of Population 5(1): $27-43$. 